\title{
Blockchain Technology: A Panacea for Corruption in Nigerian Government Financial Processes
}

\author{
Raphael Ozighor Enihe ${ }^{1}$, Taofeeqoladapo Lawal ${ }^{2}$ \\ ${ }^{I}$ Department of Computer and Information Technology, Veritas University Abuja, Nigeria \\ ${ }^{2}$ Department of Computer and Information Technology, Veritas University Abuja, Nigeria
}

\begin{abstract}
Government financial processes in Nigeria are known to lack credibility mostly because there is centralization, manipulation of accounts and lack of trust between the government officials and the citizens of Nigeria. Attempts to end or at least reduce corrupt government practices have failed miserably mostly because most processes are still manual or use systems that can be manipulated easily. Nigeria has vastly turned to spiritual mentorship, activists and whistle-blowers to curb government financial corrupt practices. However, there have been limited attempts in applying technology to solve this delicate issue. In this study the missing application of technology, that is, the application of block chain which is referred to as the technology of trust will be the in-depth focus, investigating the state-of-the-art of block chain technology, its applications and challenges of using block chain technology and providing suggestions for handling finance of the government to eradicate corruption. The study draws its data from a review of literature on major applications of block chain, data, interviews and annual reports of Nigerian government agencies and bodies. The thesis argues that block chain technology can reduce corrupt government practices and easily track all financial government processes. Thus, government should apply this technology. It also suggests, implementation models and processes. It is also concluded that the implementation of blockchain on government accounts would reduce corruption and make all transactions decentralized, unchangeable, unforgeable and highly trackable.
\end{abstract}

\section{I: INTRODUCTION}

$\mathrm{B}_{\mathrm{a}}^{\mathrm{lo}}$ lockchain is a distributed database solution that maintains a continuously growing list of data records, that are confirmed by the nodes participating in it.The data is recorded in a public ledger, including information of every transaction ever completed. Blockchain is a decentralized solution which does not require any third party organization in the middle [4]. Each block is connected to a previous block by a hash, thus enabling traceability; meanwhile, cryptography is used to guarantee that the block data cannot be tampered with and cannot be forged.



Fig 1: Structure of a block on a blockchain a structuredMichelin, R.(2020)
The creation of each block is dependent on the consensus of participants in the sequence of events and the current state of the entire system's transaction records. Each participant can record and store data, and can have backups of the entire blockchain data. The information about every transaction ever completed in Blockchain is shared and available to all nodes. This attribute makes the system more transparent than centralized transactions involving a third party.

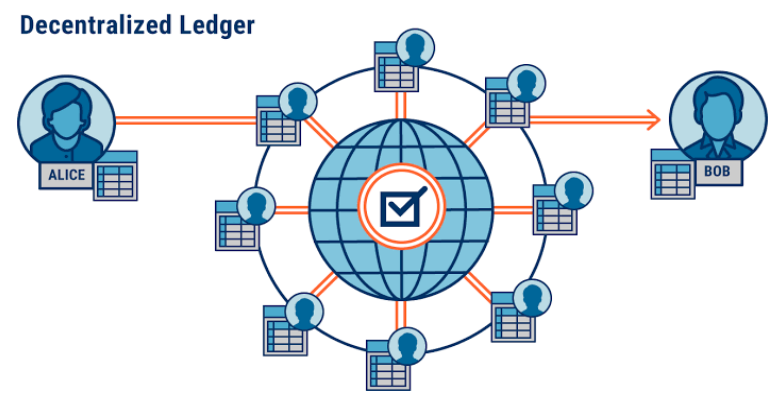

Fig 2: A Decentralized Ledger from cbinsights(2020).

In addition, the nodes in Blockchain are all anonymous, which makes it more secure for other nodes to confirm the transactions. Bitcoin was the first application that introduced Block chain technology [4], and some studies e.g [7] consider a proof-of-work consensus as the main innovation from Satoshi Nakamoto's blockchain, which is known as Bitcoin. Exactly this mechanism replaces the central authority and provides incentives that would keep members of the network honest.This honesty is what is lacking in Nigeria's goverment financial processes.

All blocks of a blockchain include transactions and hash pointer, which serves as a link to the subsequent block. In such a way, it is not possible to delete any block or insert a new one in the middle of a chain, because then hashes will not match. Blocks are created by network participants, who are processing transactions by running blockchain's client software. Such a participant is called a "node" [6]. For a block to be included in a chain all network participants must confirm its authenticity. A block is included in a chain after some definite number of confirmations; however, it is being validated by all network nodes, until everyone has an up-todate blockchain structure. Consensus can be reached in different ways, which depend on the cosensus mechanism used (proof-of-work, proof-of-stake, etc.). One of the main theory of blockchain is immutability of the recorded entries. 
Some users may try to hack the blockchain by using an automated system to set up a large number of separate identities to validate their transactions. There's a clever way ${ }^{a}$. of avoiding this problem, using an idea known as proof-ofwork and mining. As a result, a cheater would need enormous b. computational resources to cheat, making it impractical. The solution to this problem is to reward people who help validate $\mathrm{c}$. transactionseven though that's now been made a d. computationally costly process. Provided thevalue reward is large enough that will give them an incentive to participate in validation.[12].Without a central control node, a distributed peer-to-peer network has been built. Blockchain technology has many advantages such as decentralization, trustlessness, tamper resistance, and traceability.

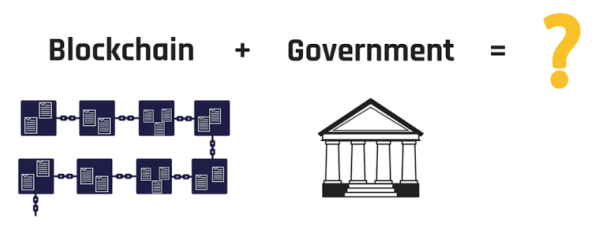

Fig 3: Blockchain and Government from BlockChainLion(2020)

Nigeria faces various corrupt practices in the government. In 2012, Nigeria was estimated to have lost over 400 billion dollars to corruption since Independence. In 2018, Nigeria Ranked $144^{\text {th }}$ in the 180 countries listed in Tran sparency International's Corruption Index with Somalia at $180^{\text {th }}$, being the most corrupt and Denmark $1^{\text {st }}$ being the least corrupt. This suggests that corruption is a major problem in Nigeria and most Nigerians have deemed it the major reason why Nigeria has not lived up to its potential and name "The Giant Of Africa".

Sadly, quite a number of government officials abuse this power and funds, entrusted to them and the citizens are made to suffer from their decisions. These abuses include stealing of funds, improper fund allocations, no salary payments, and fake/manipulated reports on government projects etc. The aforementioned actions are opposed to code of conduct for Nigerian government officials.

\section{II: LITERATURE REVIEW}

\subsection{Theoretical Concepts/Framework}

The theoretical background gives an overview of the technologies used in developing the block chain models for government and the general concept of the research topic as seen by the other researchers. The technology is chosen in other to create a more rigid system which cannot be manipulated in order to prevent government officials from carrying out various corrupt practices and thereby increase trust among government officials and citizens. The following themes are discussed; block chain models for government, the extent of block chain models for government design issues, and solutions to challenges confronting corruption government.
Some of the concepts of blockchain for government are;

Budget support and project management based on a private blockchain.

\section{Smart Contracts.}

Fraud Detection Mechanisms

\section{Cosensus Mechanisms}

\subsection{Review of related works}

In [3] it is stated that in February 2018, the US House of Representatives held two blockchain hearings in succession to explore new applications of blockchain technology. The US State Department emphasized transparency through blockchain technology to address corruption, fraud, or misappropriation of public procurement funds. The US Treasury is conducting a pilot program to determine whether blockchain technology can be used for supply chain management, and has also taken measures to improve the "Anti-Money Laundering/Combating the Financing of Terrorism (AML/CFT)“ law against blockchain-based cryptocurrencies.

South Burlington, Vermont proposes to also implement blockchain technology to record real estate transactions. California lawmakers have filed a bill that, if passed, the state's electronic record law will approve blockchain signatures and smart contracts. Although this work also state that Bitcoin is the first successful application of blockchain technology. As of now, the Bitcoin blockchain system has been in operation for more than eight years. Except for a limited number of forks, there have been no major security incidents, which fully demonstrates its strong stability and security. In my research paper I would explore indepth instances where blockchain has been unstable and which mechanisms can be implemented to prevent such occurrences from happening.

[12] acknowledges that the most widely accepted application for the blockchain technology is in the field of finance, it goes further to explain that it ensures the much valued transparency between the trading parties. Every transaction in public or private equities, stocks, bonds or derivatives could be transcripted in the blocks and afterwards be confirmed by the local authority for its legitimacy. From this point, it's easier to detect fraud cases or money laundering through stock exchange moves.

Many international development organisations provide budget support or financing for specific projects to recipient countries. These payments are often vulnerable to corruption. In 2017, German development bank KfW initiated TruBudget, a pilot project to provide budget support and project management based on a private blockchain. All stakeholders involved in a project can access the TruBudget. Requests, submissions of documents and approvals can all be processed in real time through the platform and by all the stakeholders involved. These can include a donor organisation, national 
governments, local governments, implementing agencies, banks and others. Basing the platform on the blockchain can establish trust between the different partners as data is hosted in a decentralised manner and secured against subsequent alteration. TruBudget is currently in development and is scheduled for testing soon [1].

In 2017, the World Food Programme (WFP) began a pilot programme to distribute food vouchers in one of Jordan's refugee camps using the Ethereum blockchain. Food vouchers are assigned to refugees, who can access them in supermarkets in refugee camps using biometric data. The project uses a private "fork" of the Ethereum database, so that it does not need miners to verify transactions and that the data is not stored openly on all nodes of the Ethereum network. So far, the WFP has transferred over US\$1.4 million in food vouchers to 10,500 Syrian refugees and it plans to extend the programme to 100,000 refugees in 2018 . The implementation using the blockchain runs more efficiently and provides better security against fraud [3].

\subsection{Propose contribution to Knowledge}

This study proposes models that if implemented could reduce corrupt practices drastically in Nigeria. The study would create an avenue of discussion for Nigeria to deliberate on how blockchain can be used to build trusted government financial systems.

\section{III: RESEARCH METHODOLOGY}

\subsection{Data gathering/analysis techniques}

In this research the data gathering and analysis techniques that would be used include:

- Literature review (journals, annual reports and conference papers on the chosen topic),

- Internet resources (TED talks, Online Videos etc.)

- Personal interviews.
This paper solely researches on blockchain as a panacea for corruption in Nigerian government financial processes. With no ambiguous or bias intent this research specifically on blockchain for government financial processes and what features and requirements the blockchain model would use to operate. The government processes are delicate would require a robust blockchain model to handle its processes.

\subsubsection{Planning the research.}

The collection of important and appropriate papers, resources and related to block chain and its ability to implement trust-based systems. This will the basis search to theresearch, this will carried out using internet databases for high ranking journals, conference papers in block chain and annual reports and published accounts from the Nigerian government and MDA's. The review will limited to recent studies ranging from the year 2005 to 2020 with high relevance to the topic and scope of research.

\subsubsection{Conducting the research.}

In this phase, the papers were selected and downloaded and the details of each were read carefully in order to examine its relevance to this study. Documents were reviewed. However, only papers with significant contributions were selected deliberately. As such only about twenty papers were selected and then thoroughly read, searched, and studied for relevant details that relates to the study. The date of publication of each publication will also be taken into consideration during selection in order to filter out-dated papers. These selected papers spans from 2005-date.

In carrying out this research, different databases were used such as; Research Gate, Academia.edu, Google scholar, FIRS, TED talks, Articles from THISDAY Newspaper, Scholar works and from various institutions like universities and public organizations

.Table 1. Selected journals and conference papers

\begin{tabular}{|c|c|c|c|c|c|c|}
\hline$\stackrel{\mathrm{S} /}{\mathrm{N}}$ & Journals & $\begin{array}{l}\text { Year } \\
\text { Publis } \\
\text { hed }\end{array}$ & Author & Conference Papers & $\begin{array}{l}\text { Year } \\
\text { Publi } \\
\text { shed }\end{array}$ & Author \\
\hline 1 & $\begin{array}{l}\text { Blockchain Technology as } \\
\text { an institution of property }\end{array}$ & 2017 & $\begin{array}{l}\text { G. Ishmaev } \\
\text { Metaphilosophyllc and john } \\
\text { wiley\& Vol. 48, No. 5, October } \\
2017\end{array}$ & $\begin{array}{l}\text { Blockchain Use Cases and } \\
\text { Their Feasibility }\end{array}$ & 2018 & $\begin{array}{l}\text { KasparsZīle, RenāteStrazdiņa } \\
\text { Riga Technical University, Riga, } \\
\text { Latvia. }\end{array}$ \\
\hline 2 & $\begin{array}{l}\text { “A Synopsis of Blockchain } \\
\text { Technology View } \\
\text { project”. }\end{array}$ & 2018 & $\begin{array}{l}\text { Alex Kibet. } \\
\text { Laklpla University College. } \\
\text { International Journal of } \\
\text { Advanced Research in Computer } \\
\text { Engineering \& Technology } \\
\text { (IJARCET) Volume } 7\end{array}$ & $\begin{array}{l}\text { Technology Development } \\
\text { and Application of } \\
\text { Blockchain: Current } \\
\text { Status and Challenges". } \\
\text { Institute of Computing } \\
\text { Technology, }\end{array}$ & 2018 & $\begin{array}{l}\text { Sun Yi , Fan Lingjun, Xuehai } \\
\text { Hong(2018) } \\
\text { Chinese Academy of Sciences, Beijin\& } \\
\text { University of Chinese Academy of } \\
\text { Sciences, Beijing. }\end{array}$ \\
\hline 3 & $\begin{array}{l}\text { "Sustainability of Bitcoin } \\
\text { and Blockchains," Current } \\
\text { Opinion in Environmental } \\
\text { Sustainability, }\end{array}$ & 2017 & H. Vranken & $\begin{array}{l}\text { "Where Is Current } \\
\text { Research on } \\
\text { BlockchainTechnology? } \\
\text {-A SystematicReview". } \\
\text { Article in PLoS ONE }\end{array}$ & 2016 & $\begin{array}{l}\text { Jesse Yli-Huumo, DeokyoonKo, } \\
\text { SujinChoi, Sooyong Park, Kari } \\
\text { Smolander. } \\
\text { Dept. of Innovation and Software, } \\
\text { LappeenrantUniversityof Technology, }\end{array}$ \\
\hline
\end{tabular}




\begin{tabular}{|c|c|c|c|c|c|c|}
\hline 4 & $\begin{array}{l}\text { Bitcoin and Cryptocurrency } \\
\text { Technologies. }\end{array}$ & 2016 & $\begin{array}{l}\text { Narayanan, J. Bonneau, E. Felten, } \\
\text { A. Miller, and S. Goldfeder, } \\
\text { Princeton University Press, 2016, } \\
308 \text { p. }\end{array}$ & $\begin{array}{l}\text { "On Scaling Decentralized } \\
\text { Blockchains," }\end{array}$ & 2016 & $\begin{array}{l}\text { K. Croman, C. Decker, I. Eyal, A. } \\
\text { Gencer, R. Wattenhofer et al. }\end{array}$ \\
\hline 5 & $\begin{array}{l}\text { Blockchain Technology and } \\
\text { Decentralized } \\
\text { Governance: Is the State } \\
\text { Still Necessary? Journal of } \\
\text { Governance and } \\
\text { Regulation }\end{array}$ & 2017 & Atzori, M. & $\begin{array}{l}\text { The uses of the Blockchain } \\
\text { Smart Contracts to } \\
\text { reduce the levels of } \\
\text { corruption: }\end{array}$ & 2018 & $\begin{array}{l}\text { EdimaraMezzomo Luciano, Rodrigo } \\
\text { Couto de Souza, Guilherme Costa } \\
\text { Wiedenhöft }\end{array}$ \\
\hline 6 & $\begin{array}{l}\text { "Survey of Consensus } \\
\text { Protocols on Blockchain } \\
\text { Applications," }\end{array}$ & 2014 & $\begin{array}{l}\text { L. S. Sankar, M. Sindhu, and M. } \\
\text { Sethumadhavan, } \\
\text { 4th IEEE International Conference } \\
\text { on Advanced Computing }\end{array}$ & $\begin{array}{l}\text { Further applications of the } \\
\text { blockchain". }\end{array}$ & 2015 & $\begin{array}{l}\text { Anna LaliTsilidou, Georgios Foroglou. } \\
\text { Conference Paper · University of } \\
\text { Macedonia. }\end{array}$ \\
\hline 7 & $\begin{array}{l}\text { Blockchain, bitcoin and } \\
\text { corruption :A review of } \\
\text { the linkages } \\
\text { “.Transparency } \\
\text { International Anti- } \\
\text { Corruption } \\
\text { (NiklasKossow, 2018) }\end{array}$ & 2018 & NiklasKossow, Victoria Dykes & $\begin{array}{l}\text { The Opportunities and } \\
\text { Challenges of Blockchain } \\
\text { in the Fight against } \\
\text { Government Corruption" }\end{array}$ & 2018 & $\begin{array}{l}\text { Nikita Aggarwal, Luciano Floridi } \\
\text { Feature Article in the 19th General } \\
\text { Activity Report of the Council of } \\
\text { Europe Group of States against } \\
\text { Corruption }\end{array}$ \\
\hline 8 & $\begin{array}{l}\text { "So You Want to Use a } \\
\text { Blockchain for That?," }\end{array}$ & 2016 & A. Lewis & $\begin{array}{l}\text { "A Critical Review of } \\
\text { Blockchain and Its } \\
\text { Current Applications," } \\
\text { International Conference } \\
\text { on Electrical } \\
\text { Engineerin.2017,pp. } \\
109-113 .\end{array}$ & 2017 & $\begin{array}{l}\text { B. A. Tama, B. J. Kweka, Y. Park, and } \\
\text { K. H. Rhee, }\end{array}$ \\
\hline
\end{tabular}

Table 2. Selected Videos Interview and Tutorials papers

\begin{tabular}{|c|c|c|c|c|c|c|}
\hline S/N & Video & $\begin{array}{c}\text { Year } \\
\text { Published }\end{array}$ & Author & $\begin{array}{c}\text { Interview/ } \\
\text { Tutorials }\end{array}$ & $\begin{array}{c}\text { Year } \\
\text { Published }\end{array}$ & Author \\
\hline 1 & $\begin{array}{c}\text { TED x UCLA } \\
\text { "Blockchain for a } \\
\text { better government" }\end{array}$ & 2016 & Mike Alonso & $\begin{array}{c}\text { Government } \\
\text { Accounts } \\
\text { Auditing }\end{array}$ & 2019 & Alh. TaofikLawal \\
\hline 2 & $\begin{array}{c}\text { Blockchain: The real } \\
\text { wold use cases. }\end{array}$ & 2017 & $\begin{array}{c}\text { Nick Menye } \\
\text { Enterprise } \\
\text { Architect, } \\
\text { Capgemini }\end{array}$ & & & \\
\hline 3 & $\begin{array}{c}\text { Blockchain } \\
\text { Revolution- the } \\
\text { END of } \\
\text { Representative } \\
\text { Democracy }\end{array}$ & 2016 & VisualPolitik EN & & & \\
\hline
\end{tabular}

\section{Exclusive Criteria}

All paper that included any of the following topic where excluded from our papers gathered which include; NonGovernment Organisations, Centralized systems, Unpublished papers, Year of publication less than 2005, Bias Justifications and unproven facts.

\section{Inclusive Criteria}

To choose a publication for our references we ensured that each paper consisted of all the following relevance which include; Government Organisations (with preference to Nigeria), Corruption in Nigerian Government, Decentralized database systems, Published Journals and Conference papers, Year of publication (2005-2020),Proven facts with good references.

\section{IV: ANALYSIS OF RESULTS}

\subsection{Results}

Blockchain uses Triple entry accounting, it takes general accounting further and provides a third entry which is public which means everyone can see state of every account, how much money is in circulation and look at the records of the blockchain and audit it.

If the government were on a blockchain, we would be able to easily know government expenditures on budget allocations down to the penny in under very little time, how much contractors are paid, foreign aid allocations and which departments are fraudulently wasting our money [19].

Where does block chain work well? 
i. Where there is value being transacted

ii. Busy ecosystem, not one app.

iii. Systems that lack trust

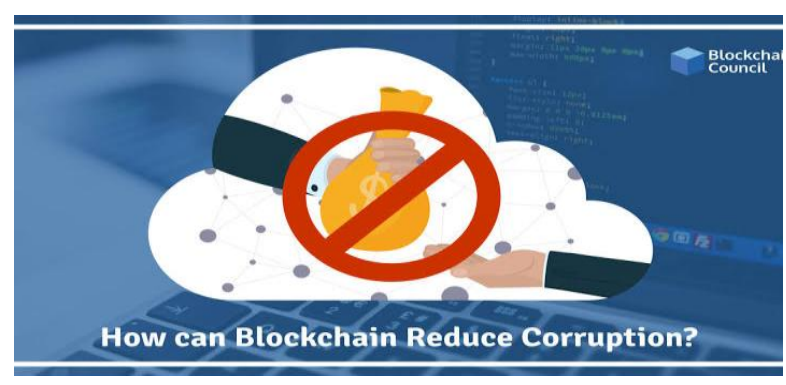

Fig 4: Ways Blockchain can reduce corruption from blockchaincouncil(2020)

For example, blockchain-based account control platforms could reduce the scope for corruption on government financial accounts by providing a tamper-proof record of incomes and expenditures that does not rely on verification by a third party and cannot be manipulated. The greater transparency and efficiency afforded by such platforms also promises to boost accountability, and to increase trust among government officials and citizens, particularly in Nigeria where corruption is a huge problem.

Among the Blockchain applications in public organizations, the following ones can be named:

i. The transfer of funds from one government level to others or from government to private companies,

ii. Smart Contracts can be used for all government payments as a way to increase transactions transparency, as well as to avoid overbilling, provided that contracts and bids are typical ways to exert frauds and money misappropriation.

The self-execution characteristic of contracts can reduce the expenses of manual payments, and also errors and delays, as well as the vulnerability to frauds and misconduct. Smart Contracts are autonomous and execute all the activities without any help or interference of any third party, showing unparalleled transparency, increasing efficiency and reducing vulnerabilities. One of these issues is the governance, which is decentralized in Blockchain, which constitutes an important variable when contracts evolve government and public funds. According to [16] challenges can vary from traditional mechanisms of State authority, citizenship and democracy. Particularly, the paper verifies to which extent Blockchain and decentralized platforms can be considered as hyper-political tools, capable to manage social interactions on large scale and dismiss traditional central authorities. According to this concept, the most important role of public organization is to create value to citizens, regardless of the technology use [15].

On December 10, 2019, it was reported by ThisDay that President Muhammadu Buhari directed the Office of the This system would require a permissioned blockchain that would be hybrid in nature and run on a secure encrypted cloud
Accountant General of the Federation (OAGF) to publish daily financial statements of federal government's transactions at the launch of a new Financial Transparency Policy/Open Treasury Portal designed to give the citizenry access to information on fiduciary matters, improve accountability and transparency in public financial management.

The policy/portal compels daily statements from the Office of the Accountant General of the Federation (OAGF) giving summary flows in and out of the treasury with a breakdown of agencies responsible. Henceforth ensure the publication of daily inflows and outflows of MDAs. To enable the implementation of the policy, the online portal, www.opentreasury.gov.ng, was activated yesterday for all MDAs to publish all the information required by the policy and for immediate access by all Nigerians [18].

\subsection{Proposed Model}

With the research done I am able to derive and build a blockchain model which can be implemented on all government accounts.

The implementation process for this model in relation to a guide by [17] would be as follows:

Step 1: Identify making government financial transactions corruption-free as our goal.

Since there are 3 things that blockchains can do very well which are Data Authentication \& Verification, Smart Asset Management and Smart Contracts.

\section{Step 2: Identify the Most Suitable Consensus Mechanism}

I recommend a Delegated Proof-Of-Stake (Their "stake" is their trustworthiness in this system) in which there will be groups who will select trusted delegates to verify each government transaction before implementation. They will also be able to remove a delegate if there are fraudulent transactions accepted on their behalf.

The original blockchain, , used proof of work as a consensus mechanism. But Proof Of Work mechanism requires high computational power and energy which is not readily available in Nigeria.The Delegated Proof-Of-Stake consensus mechanism uses less electricity, is faster and less centralized than the proof of work consensus mechanism.

\section{Step 3: Identify the Most Suitable Blockchain Platform}

There are many blockchain platforms out there today and most of them are free and open source. Some of the more popular platforms, in alphabetical order are:

BigChainDB,Corda, Ethereum, HydraChain, EOS -*Preferred Choice based on consensus algorithm

Step 4: Designing the Nodes 
platform. It will consist of Government workers, Nigerian defense and security agencies, regular citizens and religious leaders.

\section{Step 5: Design the Blockchain Instance}

Most blockchain platforms need very careful planned configuration for the following elements:

Permissions, Asset issuance, Atomic exchanges, Native assets, Key formats, Block signatures Hand-shaking are key design elements in this model. Some configurations can be changed at run-time but some cannot, so this is a very crucial step.

\section{Step 6: Building the APIs}

\section{Step 8: Adding Future Tech}

This model can be greatly enhanced by integrating Artificial Intelligence, Biometrics, Bots, Cloud, Cognitive services,
The major categories of APIs that would be needed are for:

i. Generating key pairs and addresses

ii. $\quad$ Performing audit related functions

iii. Data Authenticating Through Digital Signaturessmart Contracts

\section{Step 7: Design the Admin and User Interface}

At this stage you would need to choose the front-end and programming languages (e.g. HTML5, CSS, PHP, C\#, Java, Javascript, Python, Ruby, Golang, Solidity, Angular JS, Nodejs). You would also need to choose external databases (e.g. MySQL, MongoDB, Firebase) as well as servers (including Web servers, FTP servers, mail servers).

Containers, Data Analytics, Internet of Things and Machine Learning to provide a highly robust system.

\subsection{Process Flow of Proposed Model.}
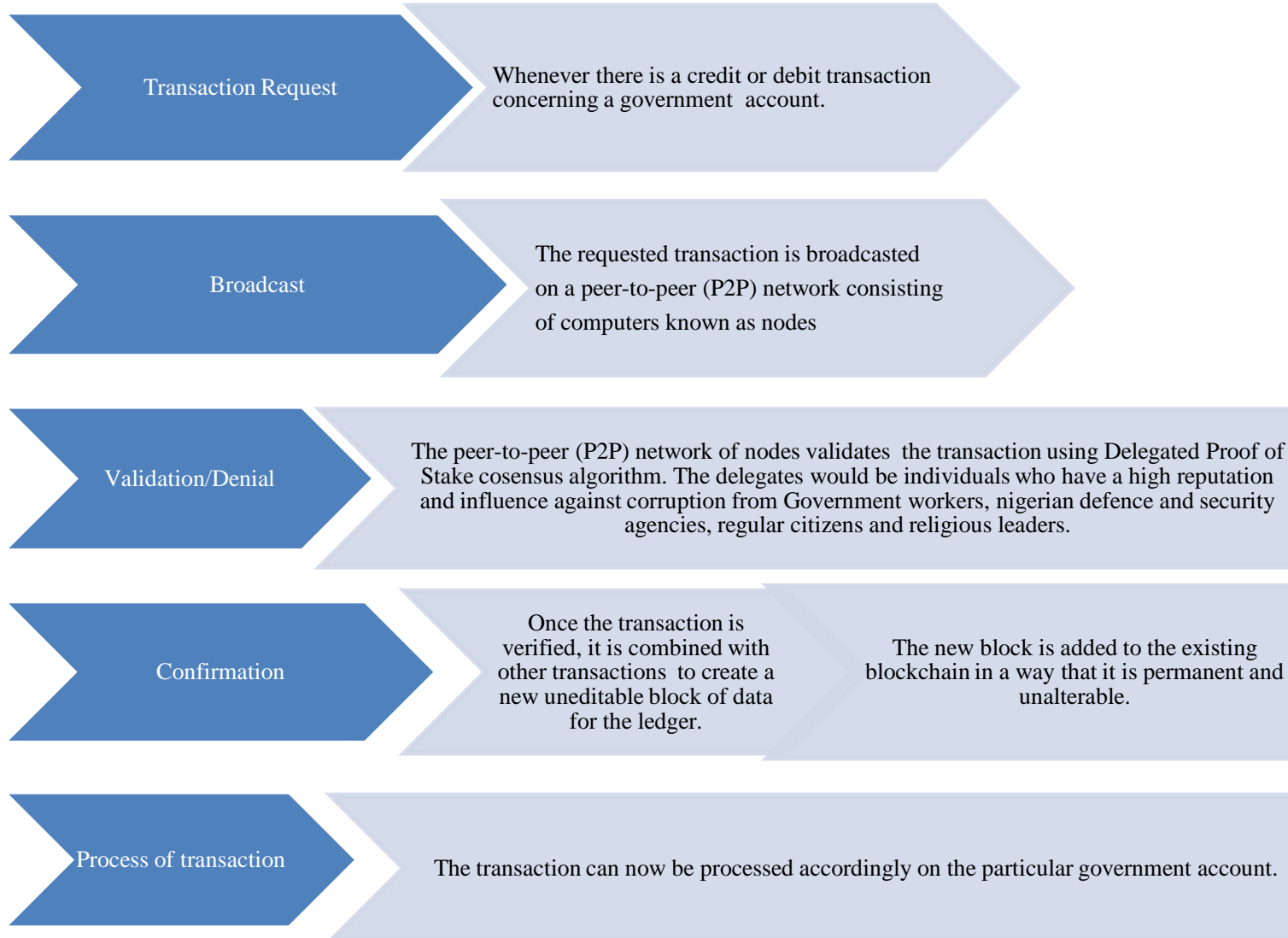

The transaction can now be processed accordingly on the particular government account.

Fig 5: Process Flow of Proposed Model. 


\section{V: FINDINGS, SUMMARY, RECOMMENDATIONS AND CONCLUSION}

\subsection{Findings}

My Findings are as follows:

- Blockchain uses Triple entry accounting.

- If the government were on a blockchain,we would be able to easily know government expenditures on budget allocations down to the penny [19].

- Blockchain works well in where there is value being transacted, Busy ecosystem, and systems that lack trust

- For example, blockchain-based account control platforms could reduce the scope for corruption on government financial accounts byproviding a tamperproof record of incomes andexpenditures that does not rely on verification by a third party and cannot be manipulated.

- Smart Contracts can be used for all government payments as a way to increase transactions transparency. The self-execution characteristic of contracts can reduce the expenses of manual payments, and also errors and delays, as well as the vulnerability to frauds and misconduct.

- The online portal, www.opentreasury.gov.ng, was activated for all MDAs to publish all the information required by the policy and for immediate access by all Nigerians but was not built on a blockchain [18].

- A Delegated Proof-Of-Stake (Their "stake" is their trustworthiness in this system) in which there will be groups who will select trusted delegates to verify each government transaction before implementation. They will also be able to remove a delegate if there are fraudulent transactions accepted on their behalf would be the best consensus mechanism.

- EOS-* Preferred Blockchain Platform based on consensus algorithm

- By integrating Artificial Intelligence, Biometrics, Bots, Cloud, Cognitive services, Containers, Data Analytics, Internet of Things and Machine Learning to provide a highly robust system.

\subsection{Discussion of Findings}

Most government reports reviewed were not detailed today-today transactions and these report figure sending were mostly "charmprices" figures that end in "9","99","95" etc. An attempt used by most sales personnel to trick the buyers and make them trust the actual cost of items. Also use of figures like "4" and "7" are also tricky as they usually standout and usually affect suserperception[20]. Therefore government reports are not trustworthy and blockchain can greatly enhance government financial processes and create a trust worthy system to the public

\subsection{Recommendation}

The following recommendations are made to help the Nigerian government implement block chain to implement transparency and reduce corruption

1. Use blockchain to reduce permissions and access to centralized government accounts.

2. Enable constant energy to allow total uptime on all nodes.

3. Creation of awareness programs on blockchain.

4. Impementation of the proposed blockchain model in the results of this research.

\subsection{Conclusion}

This study has examined how blockchain can be implemented to curb corrupt government financial practices. From the findings of the study, it can be concluded that blockchain can provide a transparent and unchangeable record of all government transactions and eradicate $70 \%$ of financially corrupt practices in Nigerian Government. Blockchain would also create an automatic ledger of all transactions concerning government accounts to make auditing easier.

\section{REFERENCES}

[1] G. Ishmaev(2017).”Blockchain Technology as an institution of property" the authorsmetaphilosophy published by metaphilosophyllc and john wiley\& sons ltd metaphilosophy Vol. 48, No. 5, October 2017 0026-1068

[2] KasparsZ̄ile, RenāteStrazdiṇa(2018).” Blockchain Use Cases and Their Feasibility “, Riga Technical University, Riga, Latvia. https://www.degruyter.com/view/j/acss.Licensed under the Creative Commons Attribution License (http://creativecommons.org/licenses/by/4.0)with De Gruyter Open.

[3] Sun Yi , Fan Lingjun, Xuehai Hong(2018)." Technology Development and Application of Blockchain: Current Status and Challenges". Institute of Computing Technology, Chinese Academy of Sciences, Beijin\& University of Chinese Academy of Sciences, Beijing.

[4] Jesse Yli-Huumo, DeokyoonKo, Sujin Choi, Sooyong Park, Kari Smolander(2016)."Where Is Current Research on Blockchain Technology?-A SystematicReview". Article in PLoS ONE - Dept. of Innovation and Software, Lappeenranta University of Technology, Lappeenranta, Finland, Dept. of Computer Science \& Engineering, Sogang University, Seoul, South Korea, Dept. of Computer Science, Aalto University, Helsinki, Finland, Sogang Institute of Advanced Technology, Sogang University, Seoul, South Korea.

[5] Alex Kibet (2018). "A Synopsis of Blockchain Technology View project”. Laklpla University College. International Journal of Advanced Research in Computer Engineering \& Technology (IJARCET) Volume 7, Issue 11, November 2018, ISSN: $2278-$ 132

[6] H. Vranken, "Sustainability of Bitcoin and Blockchains," Current Opinion in Environmental Sustainability, vol. 28, pp. 1-9, 2017. http://doi.org/10.1016/j.cosust.2017.04.011

[7] A. Narayanan, J. Bonneau, E. Felten, A. Miller, and S. Goldfeder, Bitcoin and Cryptocurrency Technologies. Princeton University Press, 2016, 308 p.

[8] B. A. Tama, B. J. Kweka, Y. Park, and K. H. Rhee, "A Critical Review of Blockchain and Its Current Applications," in International Conference on Electrical Engineering and Computer Science, 2017, pp. 109-113. https://doi.org/10.1109/ICECOS.2017.8167115 
[9] A. Lewis, "So You Want to Use a Blockchain for That?," Jul. 2016. [Online]. Available: https://www.coindesk.com/want-useblockchain/ [Accessed: 8 May 2018].

[10] L. S. Sankar, M. Sindhu, and M. Sethumadhavan, "Survey of Consensus Protocols on Blockchain Applications," in 4th IEEE International Conference on Advanced Computing and Communication Systems. https://doi.org/10.1109/ICACCS.2017.8014672

[11] K. Croman, C. Decker, I. Eyal, A. Gencer, R. Wattenhofer et al. "On Scaling Decentralized Blockchains," in International Financial Cryptography Association: FC 2016 Workshops, 2016, LNCS 9604, pp. 106-125. Available: http://fc16.ifca.ai/bitcoin/papers/CDE+16.pdf [Accessed: 8 May 2018].

[12] Anna LaliTsilidou, Georgios Foroglou. May 2015 “ Further applications of the blockchain".https://www.researchgate.net/publication/276304843 Conference Paper · University of Macedonia.

[13] NiklasKossow, Victoria Dykes. (22 January 2018)." Blockchain, bitcoin and corruption :A review of the linkages ".Transparency International Anti-Corruption (NiklasKossow, 2018)

[14] Nikita Aggarwal , Luciano Floridi "The Opportunities and Challenges of Blockchain in the Fight against Government Corruption ". (2018). Feature Article in the 19th General Activity Report of the Council of Europe Group of States against Corruption (GRECO), adopted by GRECO 82 (18-22 March 2019)(Nikita Aggarwal, 2019)

[15] EdimaraMezzomo Luciano, Rodrigo Couto de Souza, Guilherme Costa Wiedenhöft(May, 2018) The uses of the Blockchain Smart Contracts to reduce the levels of corruption: Some preliminary thoughts.Business School Pontifical Catholic University of Rio Grande do SulBrasil. (EdimaraMezzomo, 2018)

[16] Atzori, M. 2017. Blockchain Technology and Decentralized Governance: Is the State Still Necessary? Journal of Governance $\begin{array}{lllll}\text { and } & \text { Regulation. } & 6, & 1 & \text { (2017), }\end{array}$ DOI:https://doi.org/10.22495/jgr_v6_i1_p5.

[17] Nagpal, R. (2020). \#8 Steps to Build a Blockchain Solution. [online] Entrepreneur.com. Available at: https://www.entrepreneur.com/amphtml/300077 [Accessed 25 Jan. 2020].

[18] THISDAYLIVE. (2020). Buhari Orders Publication of FG's Daily Financial Transactions - THISDAYLIVE. [online] Available at: https://www.thisdaylive.com/index.php/2019/12/10/buhari-orderspublication-of-fgs-daily-financial-transactions/ [Accessed 25 Jan. 2020].

[19] Mike Alonso, (2016) "Blockchain for a better government" TED x UCLA.

[20] Alh. TaofikLawal, (2019) "Government Accounts Auditing".

[21] Nick Menye, (2017) "Blockchain : The real wold use cases"Enterprise Architect, Capgemini

[22] VisualPolitik EN, (2016). "Blockchain Revolution- the END of Representative Democracy"

\section{IMAGES}

1. Michelin, R. (2020). Blockchain block structure. [image] Available at:

2. https://www.google.com/imgres?imgurl=https $\% 3 \mathrm{~A} \% 2 \mathrm{~F} \% 2 \mathrm{Fwww}$. researchgate.net $\% 2$ Fprofile\%2FRegio_Michelin\%2Fpublication $\%$ 2F325136332\%2Ffigure\%2Ffig1\%2FAS\%3A642174639144961 $\% 401530117773650 \% 2 F B l o c k c h a i n-b l o c k-$

structure.png\&imgrefurl=https $\% 3 \mathrm{~A} \% 2 \mathrm{~F} \% 2 \mathrm{Fwww}$. researchgate.ne t\%2Ffigure \%2FBlockchain-block-

structure_fig1_325136332\&tbnid=-k6QRLdzZM-

4tM\&vet=12ahUKEwiImd6SioLoAhVXw4UKHd0zAaAQMygFe gUIARCaAQ..i\&docid=aOhxxZiTdVT16M\&w=346\&h=518\&q= structure $\% 20$ of $\% 20 \mathrm{block} \% 20 \mathrm{on} \% 20 \mathrm{a} \% 20 \mathrm{blockchain} \& \mathrm{client}=\mathrm{ms}-$ android-transsion-tecno-

rev1\&ved=2ahUKEwiImd6SioLoAhVXw4UKHd0zAaAQMygFe gUIARCaAQ [Accessed 25 Jan. 2020].
3. Cbinsights (2020). Decentralized Ledger. [image] Available at: https://www.google.com/imgres?imgurl=https $\% 3 \mathrm{~A} \% 2 \mathrm{~F} \% 2 \mathrm{Fs} 3$.am azonaws.com\%2Fcbi-research-portal-

uploads\%2F2017\%2F11\%2F20155651\%2F112017-Blockchain-4V2.png\&imgrefurl=https $\% 3 \mathrm{~A} \% 2 \mathrm{~F} \% 2 \mathrm{Fwww}$.cbinsights.com $\% 2 \mathrm{Fr}$ esearch\%2Fwhat-is-blockchain-technology\%2F\&tbnid=-

yjz2Mnt5ZcliM\&vet=12ahUKEwjm8NiIjILoAhWo2uAKHfyYDz 4QMygMegQIARBL..i\&docid=21MMXJ1untfVtM\&w=1366\&h= $760 \& \mathrm{q}=$ distributed $\% 20$ ledger $\% 20$ blockchain\&client=ms-androidtranssion-tecno-

rev1\&ved=2ahUKEwjm8NiIjILoAhWo2uAKHfyYDz4QMygMe gQIARBL [Accessed 5 Mar. 2020].

4. BlockChainLion (2020). Blockchain and Government. [image] Available at:

5. https://www.google.com/imgres?imgurl=https $\% 3 \mathrm{~A} \% 2 \mathrm{~F} \% 2 \mathrm{Fblock}$ chainlion.com\%2Fwp-

content $\% 2$ Fuploads $\% 2$ F2018\%2F01\%2Fblockchainlion-images$3-$

1024x536.png\&imgrefurl=https $\% 3 \mathrm{~A} \% 2 \mathrm{~F} \% 2 \mathrm{Fblock}$ chainlion.com $\% 2$ Fblockchain-and-

government $\% 2 \mathrm{~F} \&$ tbnid=dvxWtifTQkNE2M\&vet=12ahUKEwjp4 cLZjYLoAhUH5hoKHQT3C44QMygEegQIARAw..i\&docid=ve8 qQJ8kSwlCgM\&w=1024\&h=536\&q=blockchain\%2B\%20govern ment $\% 20 \% 3 \mathrm{D} \% 20 \% 3 \mathrm{~F} \& \mathrm{client}=\mathrm{ms}$-android-transsion-tecnorev1\&ved=2ahUKEwjp4cLZjYLoAhUH5hoKHQT3C44QMygEe gQIARAw [Accessed 5 Mar. 2020].

6. Blockchain-council.org (2020). How can blockchain stop corruption. [image] Available at:

7. https://www.google.com/imgres?imgurl=https $\% 3 \mathrm{~A} \% 2 \mathrm{~F} \% 2 \mathrm{Ffog} . \mathrm{bl}$ ockchain-council.org\%2Fwp-

content\%2Fuploads\%2F2018\%2F02\%2FHow-can-Blockchainreduce-corruption-

2000x1200.jpg\&imgrefurl=https\%3A\%2F\%2Fwww.blockchaincouncil.org\%2Fblockchain $\% 2$ Fhow-can-blockchain-reducecorruption\%2F\&tbnid=rMPEViJPBANP2M\&vet=12ahUKEwi0h 8HmkILoAhUVgHMKHfzXAo8QMygAegQIARAg..i\&docid=I MhiVJSsnqFJkM\&w=2000\&h=1200\&q=how\%20can\%20blockch ain $\% 20$ end $\% 20$ corruption\&client=ms-android-transsion-tecnorev1\&ved=2ahUKEwi0h8HmkILoAhUVgHMKHfzXAo8QMygA egQIARAg [Accessed 5 Mar. 2020]. 